\title{
Dokdonella soli sp. nov., a gammaproteobacterium isolated from soil
}

\author{
Seung-Hee Yoo, ${ }^{1}$ Hang-Yeon Weon, ${ }^{2}$ Rangasamy Anandham, ${ }^{3}$ \\ Byung-Yong Kim, ${ }^{1}$ Seung-Beom Hong, ${ }^{1}$ Young-Ah Jeon, ${ }^{1}$ \\ Bon-Sung $\mathrm{Koo}^{1}$ and Soon-Wo Kwon ${ }^{1}$
}

Correspondence

Soon-Wo Kwon swkwon@rda.go.kr

\author{
${ }^{1}$ Korean Agricultural Culture Collection (KACC), National Agrobiodiversity Center, Rural \\ Development Administration (RDA), Suwon 441-707, Republic of Korea \\ ${ }^{2}$ Mushroom Research Division, National Institute of Horticultural and Medicinal Crop Science, RDA,
Suwon 441-707, Republic of Korea \\ ${ }^{3}$ Organic Agriculture Division, National Academy of Agricultural Science, RDA, Suwon 441-707, \\ Republic of Korea
}

\begin{abstract}
An aerobic, Gram-negative, yellow-coloured, rod-shaped bacterial strain, designated $\mathrm{KIS} 28-6^{\top}$, was isolated from soil from Ulleung, an island located in the East Sea of Korea. A phylogenetic analysis revealed that strain KIS28- $6^{\top}$ was a member of the genus Dokdonella, having $16 \mathrm{~S}$ rRNA gene sequence similarities of 98.1 and $96.9 \%$ with respect to Dokdonella fugitiva CIP $108692^{\top}$ and Dokdonella koreensis DSM $17203^{\top}$, respectively. Strain KIS28-6 ${ }^{\top}$ showed DNA-DNA hybridization values of 38 and $32 \%$ with respect to $D$. fugitiva CIP $108692^{\top}$ and $D$. koreensis DSM $17203^{\top}$, respectively. The major fatty acids $(>10 \%)$ were iso- $C_{17: 1} \omega 9 c$ (35.7 \%), iso$\mathrm{C}_{17: 0}(26.9 \%)$ and iso- $\mathrm{C}_{15: 0}(11.7 \%)$, the major respiratory quinone was $\mathrm{Q}-8$ and the DNA $\mathrm{G}+\mathrm{C}$ content was $73.0 \mathrm{~mol} \%$. On the basis of the results obtained in this polyphasic taxonomic analysis, strain KIS28- $6^{\top}$ represents a novel species of the genus Dokdonella, for which the name Dokdonella soli sp. nov. is proposed. The type strain is KIS28-6 ${ }^{\top}\left(=\mathrm{KACC} 12741^{\top}=\mathrm{JCM}\right.$ $\left.15421^{\top}\right)$.
\end{abstract}

Ulleung is a South Korean island in the East Sea. The island consists primarily of trachyandesite (extrusive igneous rock) generated from volcanic eruptions that occurred about 9350 years ago. During an investigation of the presence of cultivable bacterial communities in the soils of Ulleung, we isolated a strain, designated KIS28- $6^{\mathrm{T}}$, that was found to be phylogenetically related (albeit at rather low levels of sequence similarity) to members of the genus Dokdonella of the family Xanthomonadaceae. In this study, we describe the physiological, chemotaxonomic and phylogenetic characteristics of this organism. These polyphasic taxonomic studies have revealed that strain KIS28$6^{\mathrm{T}}$ represents a novel species of the genus Dokdonella.

At the time of writing, the genus Dokdonella contains two species, namely Dokdonella koreensis and Dokdonella fugitiva; the type strains of these species were isolated from soil from Dokdo (a group of South Korean islets in

The GenBank/EMBL/DDBJ accession number for the 16S rRNA gene sequence of KIS28-6 ${ }^{\top}$ is EU685334.

A supplementary table showing the substrates utilized by strain KIS28$6^{\top}$ and representatives of Dokdonella species is available with the online version of this paper. the East Sea) and composted potting soils in Portugal, respectively (Yoon et al., 2006; Cunha et al., 2006).

Strain KIS28- $6^{\mathrm{T}}$ was isolated from soil samples collected from Ulleung $\left(37^{\circ} 30^{\prime} \mathrm{N} 130^{\circ} 52^{\prime} \mathrm{E}\right)$ by using the standard dilution plating technique and R2A medium (Difco) at $\mathrm{pH} \mathrm{7.2 \pm 0.2,} \mathrm{as} \mathrm{described} \mathrm{previously} \mathrm{(Reasoner} \mathrm{\&}$ Geldreich, 1985). One of the isolates that appeared on the R2A medium, designated strain KIS28-6 ${ }^{\mathrm{T}}$, was distinguishable by its yellow colonies; this strain was subjected to a taxonomic investigation.

The strain was cultivated at $30{ }^{\circ} \mathrm{C}$ on $\mathrm{R} 2 \mathrm{~A}$ agar for observation of the cell morphology under a light microscope and in a transmission electron microscope. All of the basic physiological and biochemical tests were performed at $30{ }^{\circ} \mathrm{C}$ as described by Gerhardt et al. (1994). The Gram reaction was determined by using a Gram-stain kit according to the instructions of the manufacturer (bioMérieux). Catalase activity was determined by assessing bubble production in $3 \%(\mathrm{v} / \mathrm{v}) \mathrm{H}_{2} \mathrm{O}_{2}$ and oxidase activity was determined using $1 \%(\mathrm{w} / \mathrm{v})$ tetramethyl- $p$ phenylenediamine. The $\mathrm{pH}$ range for growth was determined in R2A broth from pH 4.0 to 10.0 (in increments of $1.0 \mathrm{pH}$ unit): the $\mathrm{pH}$ was adjusted, prior to sterilization, by 
adding $\mathrm{HCl}$ or $\mathrm{Na}_{2} \mathrm{CO}_{3}$. Growth at various $\mathrm{NaCl}$ concentrations (1-5\%) and at various temperatures (4$50{ }^{\circ} \mathrm{C}$ ) was investigated in R2A broth and on R2A agar, respectively. Growth under anaerobic conditions was determined on R2A and on R2A supplemented with nitrite (prepared anaerobically using nitrogen) with incubation in an anaerobic chamber.

The activities of various enzymes and some physiological and biochemical properties were examined using the API 20NE and API ZYM systems (bioMérieux) according to the manufacturer's instructions. Susceptibility to the antibiotics polymyxin B, streptomycin, chloramphenicol, ampicillin, novobiocin, tetracycline, kanamycin, oleandomycin and trimethoprim (each at $50 \mu \mathrm{g} \mathrm{l}^{-1}$ ) was tested on R2A agar plates. Strain KIS28-6 ${ }^{\mathrm{T}}$ consisted of strictly aerobic, Gram-negative, rod-shaped bacteria, $0.4-0.5 \mu \mathrm{m}$ wide and $1.4-4.5 \mu \mathrm{m}$ long. Colonies were yellow, round and convex with clear margins. The strain did not grow on tryptic soy agar (TSA), nutrient agar or MacConkey agar (Difco). The ability of KIS28- $6^{\mathrm{T}}$ to produce acid from lactose and arabinose serves to differentiate this strain from $D$. fugitiva CIP $108692^{\mathrm{T}}$. Also, strain KIS28-6 ${ }^{\mathrm{T}}$ and D. koreensis DSM $17203^{\mathrm{T}}$ can be differentiated from $D$. fugitiva CIP $108692^{\mathrm{T}}$ on the basis of their hydrolysis of tyrosine and aerobic reduction of nitrate. Differential properties for KIS28- $6^{\mathrm{T}}$ and the type strains of the two recognized species of the genus Dokdonella are given in Table 1 .

The utilization of various substrates was examined in a liquid mineral salts medium containing the following $\left(\mathrm{l}^{-1}\right)$ : $\mathrm{NH}_{4} \mathrm{Cl}, \quad 1.0 \mathrm{~g} ; \quad \mathrm{K}_{2} \mathrm{HPO}_{4}, \quad 4.0 \mathrm{~g} ; \quad \mathrm{KH}_{2} \mathrm{PO}_{4}, 1.5 \mathrm{~g}$; $\mathrm{MgSO}_{4} .7 \mathrm{H}_{2} \mathrm{O}, 0.5 \mathrm{~g}$; trace-element solution, $5 \mathrm{ml}$; pH 7.0 (Mukhopadhyaya et al., 2000). The substrates (listed in Supplementary Table S1, available in IJSEM Online) were added at a concentration of $0.2 \%$ for carbohydrates and $0.1 \%$ for organic acids, alcohols and amino acids. The substrate-utilization test revealed that $D$. fugitiva CIP $108692^{\mathrm{T}}$ can be differentiated from $D$. koreensis DSM $17203^{\mathrm{T}}$ and strain KIS28- $6^{\mathrm{T}}$ on the basis of the utilization of sodium citrate, trehalose and casein. D. fugitiva CIP $108692^{\mathrm{T}}$ and D. koreensis DSM $17203^{\mathrm{T}}$ can be differentiated from strain KIS28- $6^{\mathrm{T}}$ on the basis of the utilization of succinic acid and glycine (Supplementary Table S1). Growth-factor and vitamin requirements were examined in mineral salts medium (Mukhopadhyaya et al., 2000) supplemented with $50 \mathrm{mg}$ yeast extract or $1 \mathrm{ml}$ vitamin mixture $(10 \mathrm{mg}$ biotin and $20 \mathrm{mg}$ pyridoxine in $100 \mathrm{ml}$ distilled water) $\mathrm{l}^{-1}$ and amended with the substrates listed in Supplementary Table S1. The results revealed that growth of strain KIS28- $6^{\mathrm{T}}$ increased significantly in medium amended with either yeast extract or vitamin mixture (data not shown). However, the addition of growth factors did not widen the substrate utilization of strain KIS28- $6^{\mathrm{T}}$.

Genomic DNA was isolated using the method of Ausubel et al. (1987), except that the lysates were extracted twice with chloroform to remove residual phenol. The 16S rRNA gene was amplified by using the universal primers $\mathrm{fD} 1$ and $\mathrm{rP} 2$
Table 1. Differential properties of strain $\mathrm{KIS} 28-6^{\top}$ and the type strains of Dokdonella species

Strains: 1, strain KIS28-6 ${ }^{\mathrm{T}}$; 2, D. fugitiva CIP $108692^{\mathrm{T}}$ (unless indicated, data from Cunha et al., 2006); 3, D. koreensis DSM $17203^{\mathrm{T}}$ (unless indicated, data from Yoon et al., 2006). +, Positive; (+), weakly positive; -, negative; $\mathrm{R}$, resistant; s, sensitive; ND, no data available.

\begin{tabular}{|c|c|c|c|}
\hline Characteristic & 1 & 2 & 3 \\
\hline Motility & - & - & + \\
\hline Catalase/oxidase & $+1+$ & $-/(+)$ & $+1+$ \\
\hline Motility & - & - & + \\
\hline Growth temperature $\left({ }^{\circ} \mathrm{C}\right)$ & $5-35$ & $25-45$ & $10-39$ \\
\hline Optimum growth temperature $\left({ }^{\circ} \mathrm{C}\right)$ & 30 & 40 & 30 \\
\hline Tolerance of $\mathrm{NaCl}(\%)$ & $\leqslant 1$ & $\leqslant 2$ & $\leqslant 3$ \\
\hline \multicolumn{4}{|l|}{ Acid production from:* } \\
\hline$\alpha$-Lactose & + & - & - \\
\hline L-Arabinose & + & - & + \\
\hline \multicolumn{4}{|l|}{ Hydrolysis of: } \\
\hline Tyrosine & + & $-{ }^{\star}$ & + \\
\hline Aesculin & - & $+{ }^{*} \dagger$ & - \\
\hline DNA & - & $+^{*}$ & ND \\
\hline Urea & - & $+{ }^{*} \dagger$ & - \\
\hline Aerobic nitrate reduction* & + & - & + \\
\hline$\beta$-Galactosidase & + & + & - \\
\hline \multicolumn{4}{|l|}{ Enzyme activities (API ZYM)* } \\
\hline Valine arylamidase & - & + & - \\
\hline$N$-Acetyl- $\beta$-glucosaminidase & + & - & - \\
\hline \multicolumn{4}{|l|}{ Response to antibiotics $\left(50 \mu \mathrm{g} \mathrm{ml}^{-1}\right)^{*}$} \\
\hline Polymyxin B & $\mathrm{R}$ & s & $\mathrm{R}$ \\
\hline Streptomycin & s & s & $\mathrm{R}$ \\
\hline Chloramphenicol & $\mathrm{R}$ & s & s \\
\hline Ampicillin & s & s & $\mathrm{R}$ \\
\hline Novobiocin & $\mathrm{R}$ & s & $\mathrm{R}$ \\
\hline Oleandomycin & $\mathrm{R}$ & s & $\mathrm{R}$ \\
\hline Trimethoprim & s & $\mathrm{R}$ & $\mathrm{R}$ \\
\hline DNA G $+\mathrm{C}$ content $(\mathrm{mol} \%)$ & 73.0 & 68.3 & 71.0 \\
\hline
\end{tabular}

${ }^{\star}$ Data from this study.

$\uparrow$ Negative according to Cunha et al. (2006).

(Weisburg et al., 1991) and was sequenced as described by Weon et al. (2005). Alignment of 16S rRNA gene sequences was performed with the CLUSTAL w program (Thompson et al., 1994) and a phylogenetic analysis was performed using MEGA, version 3.1 (Kumar et al., 2004). Distances were calculated using the distance options of Kimura's twoparameter model (Kimura, 1983) and clustering was determined using the neighbour-joining and maximumparsimony methods, with bootstrapping based on 1000 replicates. To determine genomic relatedness, the filter hybridization method was performed as described by Seldin \& Dubnau (1985). Probe labelling was conducted by using the non-radioactive DIG High Prime system (Roche); hybridized DNA was visualized using the DIG luminescent detection kit (Roche). DNA-DNA relatedness was quantified by using a densitometer (Bio-Rad). 
The almost-complete 16S rRNA gene sequence (1450 bp) was determined for strain KIS28- $6^{\mathrm{T}}$. Phylogenetic analysis of 16S rRNA gene sequences revealed that strain KIS28- $6^{\mathrm{T}}$ was a member of the genus Dokdonella (Fig. 1). In the neighbour-joining phylogenetic tree (Fig. 1), the strain clustered with $D$. fugitiva $\mathrm{A} 3^{\mathrm{T}}$ and $D$. koreensis DS $-123^{\mathrm{T}}$ with $100 \%$ bootstrap support. The branching order in the phylogenetic trees calculated using the neighbour joining, maximum-likelihood and maximum-parsimony methods were congruent for members of the genus Dokdonella. Strain KIS28- $6^{\mathrm{T}}$ showed the highest 16S rRNA gene sequence similarities with respect to $D$. fugitiva $\mathrm{A}^{\mathrm{T}}$ $(98.1 \%)$ and D. koreensis DS- $123^{\mathrm{T}}(96.9 \%)$, while the levels of genomic DNA relatedness with $D$. fugitiva CIP $108692^{\mathrm{T}}$ and D. koreensis DSM $17203^{\mathrm{T}}$ were 38 and $32 \%$, respectively. A bacterium that shows $16 \mathrm{~S}$ rRNA gene sequence similarity $\geqslant 97 \%$ with respect to its closest relatives is generally considered to represent a different species when the DNA-DNA reassociation level is $<70 \%$ (Wayne et al., 1987). It was concluded, therefore, that strain KIS28-6 ${ }^{\mathrm{T}}$ is genotypically distant from these type strains.

Cellular fatty acid methyl esters were prepared using bacteria grown in $\mathrm{R} 2 \mathrm{~A}$ medium for 2 days at $30{ }^{\circ} \mathrm{C}$ and were analysed using GC according to the instructions of the Microbial Identification System (MIDI). Isoprenoid quinones were analysed by means of HPLC, as described by Groth et al. (1996). DNA G +C contents were determined by means of HPLC analysis of deoxyribonucleosides, as described by Mesbah et al. (1989), using a reversed-phased column (Supelcosil LC-18-S; Supelco). The fatty acid profiles of D. fugitiva CIP $108692^{\mathrm{T}}$ and D. koreensis DSM $17203^{\mathrm{T}}$ were determined previously on buffered charcoalyeast extract and TSA, respectively (Yoon et al., 2006; Cunha et al., 2006). The novel strain was unable to grow on TSA, so we determined the fatty acid profile for KIS28 $-6^{\mathrm{T}}$, D. fugitiva CIP $108692^{\mathrm{T}}$ and D. koreensis DSM $17203^{\mathrm{T}}$ cultivated on R2A medium. The fatty acid profile of strain KIS28- $6^{\mathrm{T}}$ when grown on R2A is shown in Table 2. The results revealed the presence of iso- $\mathrm{C}_{18: 0}$ and summed feature 3 (iso- $\mathrm{C}_{15: 0} 2-\mathrm{OH}$ and/or $\mathrm{C}_{16: 1} \omega 7 c$ ) in D. fugitiva CIP $108692^{\mathrm{T}}$ cultivated on R2A. However, these fatty acids were not expressed on buffered charcoal-yeast extract medium (Cunha et al., 2006). $\mathrm{C}_{17: 1} \omega 5 c$ was not present when D. koreensis DSM $17203^{\mathrm{T}}$ was grown on TSA but was observed when this strain was grown on R2A (Table 2). This lends further support to the idea that the fatty acid profiles of bacteria vary according to the growth medium (Abu Hatab \& Gaugler, 1997; Bartholomeusz et al., 1998). The major quinone in strain KIS28- $6^{\mathrm{T}}$ was Q-8. The DNA $\mathrm{G}+\mathrm{C}$ content of the strain was $73.0 \mathrm{~mol} \%$, which is close to those reported for D. fugitiva CIP $108692^{\mathrm{T}}(68.3 \mathrm{~mol} \%)$ and D. koreensis DSM $17203^{\mathrm{T}}$ (71.0 $\left.\mathrm{mol} \%\right)$.

The ability of KIS28- $6^{\mathrm{T}}$ to grow at $5{ }^{\circ} \mathrm{C}$ and the presence of a large amount $(26.9 \%)$ of fatty acid iso- $\mathrm{C}_{17: 0}$ are features that serve to differentiate this strain from $D$. fugitiva CIP $108692^{\mathrm{T}}$. The absence of motility and the presence of $\beta$ galactosidase and $N$-acetyl- $\beta$-glucosaminidase activities are features of the novel strain that serve to differentiate it from D. koreensis DSM $17203^{\mathrm{T}}$. On the basis of the information obtained in this polyphasic investigation, including data relating to biochemical properties, the fatty acid composition, the 16S rRNA gene sequence and DNADNA hybridization, strain KIS28- $6^{\mathrm{T}}$ represents a novel species within the genus Dokdonella, for which the name Dokdonella soli sp. nov. is proposed.

\section{Description of Dokdonella soli sp. nov.}

Dokdonella soli (so'li. L. neut. gen. n. soli of soil, the source of the type strain).

Cells are aerobic, Gram-negative, non-motile rods (0.4$0.5 \mu \mathrm{m}$ wide and 1.4-4.5 $\mu \mathrm{m}$ long). Oxidase-positive and catalase-negative. Colonies on R2A are yellow, convex and round with clear margins. Growth occurs at $5-35{ }^{\circ} \mathrm{C}$ (optimally at $30{ }^{\circ} \mathrm{C}$ ) and $\mathrm{pH} 5-8$ (optimally at $\mathrm{pH} 6-7$ ). $\mathrm{NaCl}$ is not required for growth but growth occurs at $\mathrm{NaCl}$ concentrations up to $1 \%$. Positive in the methyl red test, negative in the Voges-Proskauer test and negative for $\mathrm{H}_{2} \mathrm{~S}$ production and phenylalanine deaminase activity. Acid is produced from lactose and arabinose. Growth is stimulated by the addition of yeast extract or vitamin mixture. Susceptible to $50 \mu \mathrm{g}$ streptomycin, ampicillin, tetracycline, kanamycin or trimethoprim $1^{-1}$ but not to $50 \mu \mathrm{g}$ polymyxin B, chloramphenicol, novobiocin or oleandomycin $1^{-1}$. Gelatin, tyrosine and Tween 80 are hydrolysed.

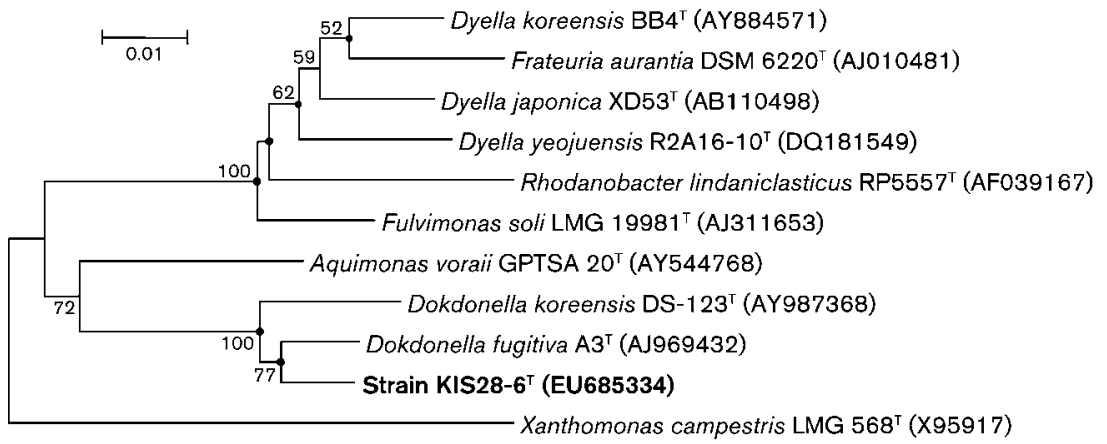

Fig. 1. Neighbour-joining phylogenetic tree, based on 16S rRNA gene sequences, showing the relationships between strain $\mathrm{KIS} 28-6^{\top}$ and closely related species. Filled circles indicate that the corresponding branches were also recovered in the maximum-parsimony phylogenetic tree. Bootstrap percentages (based on 1000 replicates) are shown at branch points; values below $50 \%$ are not shown. Bar, 0.01 changes per nucleotide position. 
Table 2. Cellular fatty acid compositions of strain $\mathrm{KIS} 28-6^{\top}$ and type strains of related species

Strains: 1, strain KIS28-6 ${ }^{\mathrm{T}}$; 2, D. fugitiva CIP $108692^{\mathrm{T}}$; 3, D. koreensis DSM $17203^{\mathrm{T}}$. Data were obtained in this study from strains cultivated on R2A medium at $30{ }^{\circ} \mathrm{C}$ and $\mathrm{pH} 7.2 \pm 0.2$ for 2 days. -, Not detected or $<1 \%$; ECL, equivalent chain-length.

\begin{tabular}{|c|c|c|c|}
\hline Fatty acid & 1 & 2 & 3 \\
\hline iso- $\mathrm{C}_{11: 0}$ & 2.5 & 1.4 & 4.2 \\
\hline iso- $\mathrm{C}_{11: 0} 3-\mathrm{OH}$ & 5.7 & 6.5 & 6.2 \\
\hline anteiso- $\mathrm{C}_{15: 0}$ & - & - & 5.3 \\
\hline iso- $\mathrm{C}_{15: 0}$ & 11.7 & 16.1 & 13.4 \\
\hline $\mathrm{C}_{16: 0}$ & 2.0 & 2.7 & 7.7 \\
\hline iso- $\mathrm{C}_{16: 0}$ & 9.5 & 11.2 & 4.4 \\
\hline iso- $\mathrm{C}_{17: 0}$ & 26.9 & 18.7 & 10.6 \\
\hline anteiso- $\mathrm{C}_{17: 0}$ & - & 1.6 & 6.2 \\
\hline $\mathrm{C}_{17: 1} \omega 5 c$ & - & - & 1.1 \\
\hline iso- $\mathrm{C}_{17: 1} \omega 9 c$ & 35.7 & 34.6 & 32.1 \\
\hline iso- $\mathrm{C}_{18: 0}$ & 1.1 & 1.0 & - \\
\hline Unknown ECL 11.799 & 1.7 & 2.9 & 1.5 \\
\hline Summed feature $3^{\star}$ & 1.2 & 1.7 & 3.5 \\
\hline
\end{tabular}

* Summed features are groups of two or three fatty acids that cannot be separated by GLC with the Microbial Identification System. Summed feature 3 contained iso- $\mathrm{C}_{15: 0} 2-\mathrm{OH}$ and/or $\mathrm{C}_{16: 1} \omega 7 c$.

Aesculin, chitin, CM-cellulose, DNA, hypoxanthine, pectin, urea and xanthine are not hydrolysed. Positive for alkaline phosphatase, esterase (C4), esterase lipase (C8), leucine arylamidase, acid phosphatase, naphthol-AS-BIphosphohydrolase and $N$-acetyl- $\beta$-glucosaminidase. Negative for indole production, glucose fermentation, arginine dihydrolase, lipase (C14), valine arylamidase, cystine arylamidase, trypsin, $\alpha$-chymotrypsin, $\alpha$-galactosidase, $\beta$-galactosidase, $\beta$-glucuronidase, $\alpha$-glucosidase, $\beta$ glucosidase, $\alpha$-mannosidase and $\alpha$-fucosidase. The major fatty acids $(>5 \%)$ when grown on $\mathrm{R} 2 \mathrm{~A}$ are iso- $\mathrm{C}_{17: 1} \omega 9 c$, iso- $\mathrm{C}_{17: 0}$, iso- $\mathrm{C}_{15: 0}$, iso- $\mathrm{C}_{16: 0}$ and iso- $\mathrm{C}_{11: 0} 3-\mathrm{OH}$. The major quinone is $\mathrm{Q}-8$. The $\mathrm{DNA} \mathrm{G}+\mathrm{C}$ content of the type strain is $73.0 \mathrm{~mol} \%$.

The type strain, KIS28- $6^{\mathrm{T}}$ (=KACC $12741^{\mathrm{T}}=\mathrm{JCM}$ $15421^{\mathrm{T}}$ ), was isolated from soil from Ulleung, a South Korean island located in the East Sea (Sea of Japan).

\section{Acknowledgements}

This work was supported by a grant (no. 20080401034028) from the BioGreen21 programme, Rural Development Administration, Republic of Korea.

\section{References}

Abu Hatab, M. A. \& Gaugler, R. (1997). Growth-mediated variations in fatty acids of Xenorhabdus sp. J Appl Microbiol 82, 351-358.

Ausubel, F. M., Brent, R., Kingston, R. E., Moore, D. D., Seidman, J. G., Smith, J. A. \& Struhl, K. (editors) (1987). Current Protocols in Molecular Biology. New York: Wiley.

Bartholomeusz, G., Zhu, Y. \& Downard, J. (1998). Growth mediumdependent regulation of Myxococcus xanthus fatty acid content is controlled by the esg locus. J Bacteriol 180, 5269-5272.

Cunha, S., Tiago, I., Pires, A. L., Da Costa, M. S. \& Veríssimo, A. (2006). Dokdonella fugitiva sp. nov., a gammaproteobacterium isolated from potting soil. Syst Appl Microbiol 29, 191-196.

Gerhardt, P., Murray, R. G. E., Wood, W. A. \& Krieg, N. R. (editors) (1994). Methods for General and Molecular Bacteriology. Washington, DC: American Society for Microbiology.

Groth, I., Schumann, P., Weiss, N., Martin, K. \& Rainey, F. A. (1996). Agrococcus jenensis gen. nov., sp. nov., a new genus of actinomycetes with diaminobutyric acid in the cell wall. Int J Syst Bacteriol 46, 234-239.

Kimura, M. (1983). The Neutral Theory of Molecular Evolution. Cambridge: Cambridge University Press.

Kumar, S., Tamura, K. \& Nei, M. (2004). MEGA3: integrated software for molecular evolutionary genetics analysis and sequence alignment. Brief Bioinform 5, 150-163.

Mesbah, M., Premachandran, U. \& Whitman, W. B. (1989). Precise measurement of the $\mathrm{G}+\mathrm{C}$ content of deoxyribonucleic acid by highperformance liquid chromatography. Int J Syst Bacteriol 39, 159-167.

Mukhopadhyaya, P. N., Deb, C., Lahiri, C. \& Roy, P. (2000). A soxA gene encoding a diheme cytochrome $c$ and a sox locus, essential for sulfur oxidation in a new sulfur lithotrophic bacterium. $J$ Bacteriol 182, 4278-4287.

Reasoner, D. J. \& Geldreich, E. E. (1985). A new medium for the enumeration and subculture of bacteria from potable water. Appl Environ Microbiol 49, 1-7.

Seldin, L. \& Dubnau, D. (1985). Deoxyribonucleic acid homology among Bacillus polymyxa, Bacillus macerans, Bacillus azotofixans, and other nitrogen-fixing Bacillus strains. Int J Syst Bacteriol 35, 151-154.

Thompson, J. D., Higgins, D. G. \& Gibson, T. J. (1994). CLUSTAL W: improving the sensitivity of progressive multiple sequence alignment through sequence weighting, position-specific gap penalties and weight matrix choice. Nucleic Acids Res 22, 4673-4680.

Wayne, L. G., Brenner, D. J., Colwell, R. R., Grimont, P. A. D., Kandler, O., Krichevsky, M. I., Moore, L. H., Moore, W. E. C., Murray, R. G. E. \& other authors (1987). International Committee on Systematic Bacteriology. Report of the ad hoc committee on reconciliation of approaches to bacterial systematics. Int J Syst Bacteriol 37, 463-464.

Weisburg, W. G., Barns, S. M., Pelletier, D. A. \& Lane, D. J. (1991). $16 \mathrm{~S}$ ribosomal DNA amplification for phylogenetic study. J Bacteriol 173, 697-703.

Weon, H. Y., Kim, B. Y., Kwon, S. W., Park, I. C., Cha, I. B., Tindall, B. J., Stackebrandt, E., Trüper, H. G. \& Go, S.-J. (2005). Leadbetterella byssophila gen. nov., sp. nov., isolated from cotton-waste composts for the cultivation of oyster mushroom. Int J Syst Evol Microbiol 55, 2297-2302.

Yoon, J. H., Kang, S. J. \& Oh, T. K. (2006). Dokdonella koreensis gen. nov., sp. nov., isolated from soil. Int J Syst Evol Microbiol 56, 145-150. 